\title{
Immunodeficient Rabbit Models: History, Current Status and Future Perspectives
}

\author{
Jun Song ${ }^{1} \mathbb{(}$, Brooke Pallas ${ }^{1,2}$, Dongshan Yang ${ }^{1}$, Jifeng Zhang ${ }^{1}{ }^{\oplus}$, Yash Agarwal ${ }^{3}$, \\ Y. Eugene Chen ${ }^{1}$, Moses Bility ${ }^{3, *}$ and Jie $\mathrm{Xu}^{1, * \mathbb{D}}$ \\ 1 Center for Advanced Models and Translational Sciences and Therapeutics, University of Michigan, \\ Ann Arbor, MI 48109, USA; songjun@med.umich.edu (J.S.); bpallas@med.umich.edu (B.P.); \\ doyang@umich.edu (D.Y.); jifengz@umich.edu (J.Z.); echenum@umich.edu (Y.E.C.) \\ 2 Unit for Laboratory Animal Medicine, University of Michigan Medical School, Ann Arbor, MI 48109, USA \\ 3 Department of Infectious Diseases and Microbiology, Department of Epidemiology, Graduate School of \\ Public Health, University of Pittsburgh, Pittsburgh, Public Health, Pittsburgh, PA 15261, USA; \\ YAA30@pitt.edu \\ * Correspondence: mtbility@pitt.edu (M.B.); jiex@med.umich.edu (J.X.)
}

Received: 16 September 2020; Accepted: 18 October 2020; Published: 21 October 2020

\begin{abstract}
Production of immunodeficient (ID) models in non-murine animal species had been extremely challenging until the advent of gene-editing tools: first zinc finger nuclease (ZFN), then transcription activator-like effector nuclease (TALEN), and most recently clustered regularly interspaced short palindromic repeats-associated protein 9 (CRISPR)/Cas9. We and others used those gene-editing tools to develop ID rabbits carrying a loss of function mutation in essential immune genes, such as forkhead box protein N1 (FOXN1), recombination activating gene 1/2 (RAG1/2), and interleukin 2 receptor subunit gamma (IL2RG). Like their mouse counterparts, ID rabbits have profound defects in their immune system and are prone to bacterial and pneumocystis infections without prophylactic antibiotics. In addition to their use as preclinical models for primary immunodeficient diseases, ID rabbits are expected to contribute significantly to regenerative medicine and cancer research, where they serve as recipients for allo- and xeno-grafts, with notable advantages over mouse models, including a longer lifespan and a much larger body size. Here we provide a concise review of the history and current status of the development of ID rabbits, as well as future perspectives of this new member in the animal model family.
\end{abstract}

Keywords: immunodeficient rabbits; gene editing; animal models

\section{The Pre-Gene-Editing Age Where Mice Dominated}

The development of germline transmitting mouse embryonic stem cells (mESCs) in the 1980s enabled versatile gene targeting manipulations, especially gene knockout (KO), in this species [1-4]. Many mouse models have been generated by utilizing mESCs. Unfortunately, except for rats, no germline transmitting ESCs have been generated in any other mammalian species despite over two decades of effort. Consequently, mouse models have been and remain the dominant animal model in biomedical research, representing greater than $70 \%$ of all mammalian models to date [5].

Immunodeficiencies (IDs), caused by mutations in genes affecting lymphocyte development or function such as interleukin 2 receptor subunit gamma (IL2RG) (OMIM\# 300400), recombination activating gene 1 (RAG1) or recombination activating gene 2 (RAG2) (OMIM\# 601457), and PRKDC (OMIM\# 600899), are deadly human diseases in which patients are highly susceptible to bacterial, viral, and fungal infections in early infancy and are subject to opportunistic infections in the lungs and gastrointestinal tracts, due to their impaired immune system [6]. 
Mouse models carrying loss of function mutations in essential ID-causing genes have been established [7]. In addition to their use as models for primary ID and acquired ID (e.g., AIDS) diseases, ID mice are widely used for allo- and xeno-graft experiments, taking advantage of their compromised immune rejection responses. The following are several generations of ID mouse models [8], each with increasing immunodeficiency:

i. $\quad$ Nude mice (Foxn1 $1^{--}$). Forkhead box protein N1 (Foxn1) encodes a transcription factor required for both hair follicle and thymic development. KO of Foxn1 leads to a hairless phenotype and a failure of thymus development;

ii. SCID (severe combined immunodeficiency) mice $\left(\operatorname{Prkdc^{--}}\right)$ or Rag deficient $\left(\operatorname{Rag} 1 / 2^{--}\right)$mice. Prkdc encodes a polypeptide that is essential for the repair of double-strand breaks (DSBs) in the DNA; the breaks occur during somatic recombination of T cell receptor (TCR) and immunoglobulin (Ig) genes. The loss of Prkdc leads to T and B cell deficiency. Rag1 and Rag2 cluster closely in the genome and are critical elements for somatic recombination of TCR and Ig genes. The absence of Rag1 or 2 also results in both $\mathrm{T}$ and $\mathrm{B}$ cell deficiency.

iii. Il2rg deficiency on either the Prkdc or Rag deficient background. IL2rg mediates IL2, IL4, IL7, IL9, and IL15 high affinity signaling, which promotes the development of a myriad of immune cells.

iv. Additionally, the NOD/ShiLtJ strain exhibits deficiency in innate immune response, specifically, NK cells and antigen-presenting cells (i.e., macrophages). Coupling the previously described Prkdc or Rag mutation along with the Il2rg deficiency on a NOD background results in multigenic immunodeficiency, and a severely immunodeficient mouse model. Examples include NOD-Prkdc $c^{\text {scid }}$ IL2rg ${ }^{\text {Tm1Wjl }}$ (NSG) and NOD-Rag1/2 ${ }^{\text {scid }}$ IL2rg ${ }^{\text {Tm1Wjl }}$ (NRG) lines.

ID mouse models have made invaluable contributions to basic and translational research in biomedicine. However, as in any other field, "no model is perfect", and ID mouse models have their limitations, specifically due to their relatively short lifespan ( $1 \mathrm{y})$ and small size $(25 \mathrm{~g})$. Their short lifespan prohibits experiments greater than $1 \mathrm{y}$, such as those following long term efficacy and safety parameters in regenerative medicine. Their small size makes organ transplantation and other experimental technical manipulations extremely challenging, if not impossible. Prior to the gene editing age, unfortunately, researchers had no other choice but to use what was available (i.e., mouse models) rather than what was clinically relevant.

\section{The Gap between Mice and Humans}

Nevertheless, it has long been realized that there is a preclinical research gap that is unmet by rodent models [9], including ID mouse models, especially when it comes to long term studies and those that involve sophisticated manipulations.

Interventional studies that require long-term follow-up are not feasible in ID mice. For example, gene therapy offers tremendous hope for a permanent cure for SCID patients. In the late 1990s, gene therapy for X-SCID was conducted using a gamma-retroviral vector [10]. Correction of the disease phenotype and clear clinical benefit proved the principle of using this strategy to treat X-SCID effectively. However, the reported success was tempered by the demonstration of leukemic proliferation in 5 of 20 patients $2.5-5.5 \mathrm{y}$ after the gene therapy [11,12]. In all cases, evidence pointed to the integration of the vector in the vicinity of oncogenes (LMO2 or CCND2) [13]. Such long-term safety risks are undoubtedly impossible to reveal by a mouse model.

Sophisticated manipulations are limited by the small size of anatomical structures and the frailty of ID mice. Vascular bypass grafting, for example, is an effective treatment for ischemic heart disease and peripheral vascular disease. In the US, there are more than 200,000 arterial bypass operations performed annually. However, many patients who require arterial bypass procedures do not have suitable vessels for use. In recent years, patient-specific stem cells (i.e., induced pluripotent stem cell)-derived blood vessels (SDBV) represent a potential solution to this problem. To advance SDBV to clinical applications, robust efficacy and safety data must be collected in preclinical animal models, 
where ID animal models are preferred to minimize immune rejections associated with this xeno-graft procedure. One major technical challenge using ID mice for this purpose is the tiny size of their blood vessels, making surgical transplantation very difficult.

\section{Gene Editing Tools and the Rise of Non-Murine Immunodeficient Animal Models}

The development of efficient gene editing tools eventually enabled the production of ID animal models in non-murine species. The past decade witnessed the advent of three generations of gene editing nucleases: zinc finger nucleases (ZFNs), transcription activator-like effector nucleases (TALENs), and, most recently, clustered regularly interspaced short palindromic repeats (CRISPR)/CRISPR-associated protein 9 (CRISPR/Cas9).

ZFN is the first-generation programmable gene-editing nuclease. In 2009, ZFN was successfully used to achieve efficient gene targeting in mammalian cells [14]. ZFN consists of the zinc finger DNA-binding domains and the DNA cleavage domain of a Type II restriction enzyme Fok1. The zinc finger domains are programmable, and a unique set of zinc fingers can be constructed to target a unique DNA sequence. The DNA cleavage domain Fok1 only works when two Fok1s are paired. Therefore, in a typical ZFN-mediated gene targeting, a pair of ZFNs are designed to flank the target locus such that the two Fok1 domains (one from each ZFN) will meet and induce site-specific double-strand breaks (DSBs) in the DNA, which leads to targeted modification of the genome.

TALENs were first reported in 2011 [15,16]. Like ZFNs, TALENs also work in a pair, where two Fok1s generate DSBs at the target locus in a scissors-like manner. Instead of using zinc fingers, TALENs use TAL DNA binding domains targeting the desired sequence. The TALEN DNA binding domain contains a repeated highly conserved 33-34-amino-acid sequence, except for the 12th and 13th amino acids, which are highly variable (repeat variable diresidue, RVD) and show a strong correlation with specific nucleotide recognition $[17,18]$. The simple relationship between the amino acid sequence and DNA recognition has made it easy to design and it is relatively practical compared with ZFN technology.

Only two years after TALEN was adopted, the third-generation tool, CRISPR/Cas9, emerged and quickly dominated the field $[19,20]$. Originally discovered as the bacterial adaptive immune machinery, CRISPR/Cas9 contains two endonuclease domains by itself (i.e., no need to fuse an exogenous nuclease such as Fok1). The most significant difference between CRISPR/Cas9 and its predecessors is that it uses nucleic acid complementation for target recognition. In this way, the tedious protein engineering work to construct sequence-specific zinc fingers or TALs is bypassed. Instead, a complement 20 nucleotide RNA sequence is used, which can be quickly and easily designed and constructed.

These programmable nucleases were quickly adapted in animal model development to bypass the need for germline transmitting ESCs [21]. The technical procedure is similar to that of the pronuclear DNA microinjection, which is used for the production of conventionally transgenic animals. Briefly, targeting elements (ZFN, TALEN, or Cas9) are microinjected into pronuclear stage animal embryos in the format of plasmid DNA, mRNA, or protein. The gene-editing nuclease would generate DSBs in the embryo genome; however, the efficiency is very much sequence-dependent. Many of the offspring animals carry mutations at the target locus, which can be used to establish mutant animal lines through routine herd expansion strategies.

The production of ID non-murine animal models boomed after 2009. Prior to that, only naturally occurring ID horses and dogs were established through selective breeding [22-27]. In the past ten years ID rabbits, rats, pigs, hamsters, and non-human primates have been reported from different laboratories across the world (Tables 1 and 2). Among these animal models, ID rats, pigs, and rabbits represent the majority, consistent with the impact of the corresponding model species in the biomedical research community. 
Table 1. Production of immunodeficient (ID) non-murine animal models (except rabbits). The "Method" row indicates the debut year of the method. G: gene targeting refers to the conventional gene editing nuclease-free, homologous recombination-based gene targeting method. M: meganuclease refers to an I-CreI based nuclease.

\begin{tabular}{|c|c|c|c|c|c|c|c|c|c|c|c|c|c|}
\hline Year & Pre 2009 & 2009 & 2010 & 2011 & 2012 & 2013 & 2014 & 2015 & 2016 & 2017 & 2018 & 2019 & 2020 \\
\hline \multirow[t]{2}{*}{ Metho } & B: breeding & $\begin{array}{c}\text { Z: } \\
\text { ZFN }\end{array}$ & & $\begin{array}{c}\text { T: } \\
\text { TALEN }\end{array}$ & & $\begin{array}{c}\text { C: } \\
\text { Cas9 }\end{array}$ & & & & & & & \\
\hline & $\begin{array}{c}\text { G: gene } \\
\text { targeting } \\
\text { M: } \\
\text { meganuclease }\end{array}$ & & & & & & & & & & & & \\
\hline $\begin{array}{l}\text { IL2RG } \\
\text { Dog }\end{array}$ & B $[24,25]$ & & & & & & & & & & & & \\
\hline Rat & & & $\begin{array}{c}Z \\
{[28]}\end{array}$ & & $\begin{array}{c}Z \\
{[29]}\end{array}$ & & & & & & $\begin{array}{c}\mathrm{C} \\
{[30]}\end{array}$ & $\begin{array}{c}\text { C } \\
{[31]}\end{array}$ & \\
\hline & & & & & & & & & & & $\begin{array}{c}\mathrm{T} \\
{[32]}\end{array}$ & & \\
\hline Pig & & & & & $\begin{array}{c}G \\
{[33]}\end{array}$ & $\begin{array}{c}Z \\
{[34,} \\
35]\end{array}$ & & & $\begin{array}{c}G \\
{[36]}\end{array}$ & & & & $\begin{array}{c}\mathrm{C} \\
{[37]}\end{array}$ \\
\hline & & & & & & & & & $\begin{array}{c}\mathrm{T} \\
{[38]} \\
\mathrm{C} \\
{[39,} \\
40]\end{array}$ & & & & \\
\hline NHP & & & & & & & & & $\begin{array}{l}\mathrm{Z} / \mathrm{T} \\
{[41]}\end{array}$ & & & & \\
\hline Rag1 & & & & & & & & & & & & & \\
\hline Rat & & & & & $\begin{array}{c}\mathrm{Z} \\
{[42]}\end{array}$ & $\begin{array}{c}\mathrm{M} \\
{[43]}\end{array}$ & & & & & & $\begin{array}{c}\mathrm{C} \\
{[31]}\end{array}$ & \\
\hline Pig & & & & & & & $\begin{array}{c}\mathrm{G} \\
{[44]} \\
\mathrm{T} \\
{[45]}\end{array}$ & & & & & & \\
\hline Hamster & & & & & & & & & & & $\begin{array}{c}\mathrm{C} \\
{[46]}\end{array}$ & & \\
\hline Rag2 & & & & & & & & & & & & & \\
\hline Rat & & & & & & & & $\begin{array}{c}\mathrm{T} \\
{[47]}\end{array}$ & & & $\begin{array}{c}\mathrm{T} \\
{[48]}\end{array}$ & $\begin{array}{c}\mathrm{C} \\
{[31]}\end{array}$ & \\
\hline Pig & & & & & & & $\begin{array}{c}\mathrm{T} \\
{[45,} \\
49]\end{array}$ & & $\begin{array}{c}G \\
{[36]}\end{array}$ & & & & \\
\hline & & & & & & & & & $\begin{array}{c}\mathrm{C} \\
{[40]}\end{array}$ & & & & \\
\hline $\operatorname{IgM}$ & & & & & & & & & & & & & \\
\hline Rat & & & $\begin{array}{c}\mathrm{Z} \\
{[50]}\end{array}$ & & & & & & & & $\begin{array}{c}\text { C } \\
{[51]}\end{array}$ & & \\
\hline Pig & & & & & & & & $\begin{array}{c}\mathrm{C} \\
{[52]}\end{array}$ & & & & & \\
\hline $\begin{array}{l}\text { Prkdc } \\
\text { Dog } \\
\text { Horse }\end{array}$ & $\begin{array}{c}\text { B }[26,27,53] \\
\text { B }[22,23]\end{array}$ & & & & & & & & & & & & \\
\hline Rat & & & & & $\begin{array}{c}Z \\
{[29]}\end{array}$ & & & & & & $\begin{array}{c}\mathrm{C} \\
{[30]}\end{array}$ & & \\
\hline Foxn1 & & & & & & & & & & & & & \\
\hline Rat & & & & & & & & & $\begin{array}{c}\mathrm{C} \\
{[54]}\end{array}$ & & & & \\
\hline Artemis & & & & & & & & & & & & & \\
\hline Pig & & & & & & $\begin{array}{c}\text { B } \\
{[55]}\end{array}$ & & $\begin{array}{c}\text { B } \\
{[56]}\end{array}$ & & & & & \\
\hline
\end{tabular}

IL2RG: interleukin 2 receptor subunit gamma; Rag1: recombination activating gene 1; Rag2: recombination activating gene 2; IgM: immunoglobulin M; Prkdc: protein kinase, DNA-activated, catalytic subunit; Foxn1: forkhead box protein N1. Artemis: a protein coded by the DCLRE1C (DNA cross-link repair 1C) gene. 
Table 2. Production of immunodeficient rabbits. The "Method" row indicates the debut year of the method. Tg: transgenic, refers to the conventional method used in transgenic animal production, without the use of gene editing nucleases or any other gene targeting methods.

\begin{tabular}{|c|c|c|c|c|c|c|c|c|c|c|c|c|c|}
\hline Year & Pre 2009 & 2009 & 2010 & 2011 & 2012 & 2013 & 2014 & 2015 & 2016 & 2017 & 2018 & 2019 & 2020 \\
\hline Method & $\begin{array}{c}\text { Tg: } \\
\text { transgenic }\end{array}$ & $\begin{array}{c}\mathrm{Z}: \\
\mathrm{ZFN}\end{array}$ & & $\begin{array}{c}\text { T: } \\
\text { TALEN }\end{array}$ & & $\begin{array}{c}\text { C: } \\
\text { Cas9 }\end{array}$ & & & & & & & \\
\hline VDJ-Cmu & $\operatorname{Tg}$ [57] & & & & & & & & & & & & \\
\hline IL2RG & & & & & & & & & & $\begin{array}{c}\mathrm{C} \\
{[58]}\end{array}$ & & & $\begin{array}{c}C \\
{[59]}\end{array}$ \\
\hline Rag1 & & & & & & $\begin{array}{c}\mathrm{T} \\
{[60]}\end{array}$ & & & & $\begin{array}{c}\mathrm{C} \\
{[58]}\end{array}$ & & & \\
\hline Rag2 & & & & & & $\begin{array}{c}\mathrm{T} \\
{[60]}\end{array}$ & & & & $\begin{array}{c}\mathrm{C} \\
{[58]}\end{array}$ & & & \\
\hline $\operatorname{IgM}$ & & & & $\mathrm{Z}$ [61] & & & & & & & & & \\
\hline Prkdc & & & & & & & & & & $\begin{array}{c}\text { C } \\
{[58]}\end{array}$ & & & \\
\hline Foxn1 & & & & & & & & & & $\begin{array}{c}\mathrm{C} \\
{[58]}\end{array}$ & & & \\
\hline
\end{tabular}

VDJ-Cmu: a transgene that codes the V, D, J and the constant region of the mu chain of immunoglobulin; IL2RG: interleukin 2 receptor subunit gamma; Rag1: recombination activating gene 1; Rag2: recombination activating gene 2; IgM: immunoglobulin M; Prkdc: protein kinase, DNA-activated, catalytic subunit; Foxn1: forkhead box protein N1.

The five significant immune genes, $I l 2 r g$, Rag1/2, Prkdc, and Foxn1 that are deficient in ID mouse lines, have all been targeted in rats and pigs (Table 1). The phenotypes (i.e., immunodeficiency) of these animals are in line with those observed in ID mice with the same gene knockout. In addition to these five genes, IgM is targeted in rats and pigs, likely part of an effort to destroy the endogenous immunoglobulin system to introduce human immunoglobulin genes in order to humanize these animals for antibody discovery practices. Artemis, a protein coded by the DCLRE1C (DNA cross-link repair $1 C$ ) gene that plays an essential role in $\mathrm{V}(\mathrm{D}) \mathrm{J}$ recombination, was also targeted to produce Artemis KO pigs $[55,56]$.

There is a clear pattern regarding the specific nuclease that is used for producing ID rats and pigs: ZFN dominated from 2010 to 2012 (Table 1), then was replaced by TALEN from 2013 to 2015, and was replaced by CRISPR/Cas9 from 2016 and thereafter. The first reports of any given nuclease used in ID animal production typically occurred 1 to 2 years later than the original introduction of that nuclease, which is expected considering the time that is required to adopt the technology, to produce the animals, and to publish the paper. Nevertheless, this pattern clearly reflects the research community's preference regarding the type of nuclease used in gene editing work over the past decade.

\section{The Birth of Immunodeficient Rabbits}

The rabbit (Oryctolagus Cuniculus) is a classic laboratory animal model species and is increasingly becoming a translational model of choice for bridging the gap between rodent models and larger animal models [62-71]. The method to produce transgenic rabbits by pronuclear microinjection is well-established and comprehensively described [72].

The significant advantages of rabbit models over ID mouse models are their longer lifespan and larger size. A New Zealand White (NZW) rabbit housed in a specific pathogen-free (SPF) animal facility can live beyond six years, and adult NZW rabbits are similar in weight and size to human infants. In the context of ID, rabbit models would extend studies past one year, such as those required for gene therapy development, and allow sophisticated xenotransplantation procedures. We also note that the rabbit is a classic animal model for the study of immunology [73-75]. They are used for the study of viral [76-78] and bacterial infectious diseases and in particular S. aureus infections in the lungs, which is a significant pathogen in human SCID patients [79]; therefore an ID rabbit model may better reflect $S$. aureus infection-related pathologies in immunodeficient patients than do mouse models. Compared to other large animals such as pigs and non-human primates, the rabbit is a more affordable 
lab animal species that can be easily housed in most research institutes. In addition, rabbits possess a short gestational period of 30-31 days, and routinely produce relatively large litters of 4 to 12 kits, allowing efficient herd expansion.

Although these features make ID rabbits a promising model to be developed, the production of gene-targeted transgenic (GTT) (e.g., knockout, knock-in) rabbits has been a challenge. Efforts to produce GTT rabbits date back to the 1980s, but unfortunately, all gene targeting attempts failed until ZFN became available in 2009. This is mainly due to the lack of germline ESCs [80], and the extremely low efficiency of somatic cell nuclear transfer (SCNT) in rabbits [81]. ESCs are the primary tool to generate GTT mice, and SCNT has been successfully applied to generate $\mathrm{KO}$ animals in species lacking germline transmitting ESCs such as pigs [82-84], sheep [85,86] and cattle [87], but not in rabbits. As a result, no ID rabbits have yet been produced by the ESC or SCNT approach.

Interestingly, the laboratory of Katherine Knight at Loyola University (Chicago, IL, USA), who first established a working protocol to establish rabbit monoclonal antibodies, generated the first ID rabbit line accidentally [57]. They initially worked to produce IgH-transgenic rabbits carrying a productive VDJ-C $\mu$ sequence. Instead of obtaining B-cells producing the immunoglobulins coded by the recombinant VDJ-C $\mu$, they found that these transgenic rabbits were B-cell deficient, with a $50-100 \%$ reduction in serum IgM and IgG levels. Nevertheless, the production of this ID rabbit line was accidental, unexpected, untargeted, and not reproducible.

The first report of ID rabbit production through targeted gene editing, and also the first report of GTT rabbit production in a broader scope, came in 2011, two years after ZFN appeared in the scientific toolbox. Flisikowska and colleagues from the Technical University of Munich, Roache Diagnostics $\mathrm{GmBH}$, and Sangamo BioSciences reported the production of immunoglobulin M (IgM) knockout rabbits by microinjecting ZFN mRNAs to pronuclear stage rabbit embryos [61]. They demonstrated that ZFN efficiently disrupted the target gene, in ex vivo cultured embryos, and ultimately in offspring kits born after embryo transfer. The IgM knockout rates were high, ranging from 23 to $35 \%$, calculated as the number of positive $\mathrm{KO}$ founders per born kits. The $\mathrm{KO}$ rates were magnitudes higher than those of prior efforts of gene targeting in rabbit cells, which were in the range of $<0.1 \%$ to $<\sim 1 \%$ (unpublished data and personal communications). They further demonstrated that the ZFN-introduced mutant alleles transmitted to the next generation animals, satisfied the golden standard of a successful GTT method. Lastly, they showed that gene knockout of IgM, as predicted, led to serum IgM and IgG deficiency and lack of IgM+ and IgG+ B lymphocytes in homozygous $\mathrm{KO}$ animals.

The success of Flisikowska et al. opened a new possibility in biomedical research, i.e., efficient production of GTT rabbits. The entire research community is no longer bound by the lack of rbESCs to achieve this goal. Nevertheless, it did not take long before the second-generation gene-editing tool TALEN came into play. Compared to ZFN, TALEN has several significant advantages: design and construction are easier, and the efficiency is comparable and often higher.

In 2013 Dr. Liangxue Lai's group in Guangzhou China obtained Rag1/2 KO rabbits by embryo microinjection of TALENs mRNA, the first (and the only to date) report using TALEN for ID rabbit production [60]. The KO efficiency in founders was exceptionally high, reaching $94 \%$ for Rag1 and 100\% for Rag2, representing a 3 to 4 -fold higher efficiency than those in the ZFN IgM work. The authors found that a high percentage of founder animals carried bi-allelic modifications ( $61 \%$ for Rag1; $100 \%$ for Rag2). As a result, the founder-generation of RAG deficient rabbits displayed typical ID phenotypes with defective $\mathrm{T}$ and $\mathrm{B}$ cell populations.

Only one year after the first TALEN report, Lai's group used the third-generation tool CRISPR/Cas9 and first produced Il2rg knockout rabbits [88]. Again, the KO efficiency reached $100 \%$ such that all kits born after microinjection/embryo transfer carried mutant alleles. The authors then demonstrated the multiplex capacity of CRISPR/Cas9 by producing I2lrg/Rag1 double knockout rabbits in one round of microinjection/embryo transfer. Comparing to TALEN, the CRISPR/Cas9 system is easier to set up, faster, cheaper, and has similar or higher targeting efficiencies. These favorable traits soon made it the dominant tool in ID rabbit production. 
In 2017, Xu's group at the University of Michigan produced multiple lines of ID rabbits, including FOXN1, RAG2, IL2RG, and PRKDC knockouts by multiplex sgRNA microinjection and multiplex embryo transfer [58]. In the multiplex sgRNA microinjection approach, different sgRNAs targeting different genes were pooled and microinjected to the same embryo, leading to the production of founder rabbits carrying multiple gene knockouts. One such animal named "NuSRG" had mutations in all these genes: Foxn1 (nude), Prkdc (SCID), Rag2 and Il2Rg. This NuSRG rabbit was hairless and severely immunodeficient. In the multiplex embryo transfer approach, embryos injected with different individual sgRNAs were pooled and transferred to the same recipient, leading to the production of different gene knockout founders in one litter. The authors were able to produce four single-gene knockout founders (i.e., Foxn1, Rag2, Il2rg, and Prkdc KOs) in one embryo transfer litter. The same group later established Foxn1, Rag2, and Il2rg KO rabbit lines; all displayed typical ID phenotypes. In a comprehensive characterization report by this group [79], Song et al. showed that IL2RG-null rabbits demonstrated severe combined immunodeficiency, characterized by the absence of pronounced hypoplasia of the thymus and splenic white pulp, and absence of immature and mature T and B-lymphocytes in the peripheral blood. Without prophylactic antibiotics, the ID rabbits universally succumbed to lung infections caused by Bordetella bronchiseptica in several animals, but by Pneumocystis oryctolagi in all animals. Their findings were recently confirmed by Hashikawa et al. from Osaka University, Japan, where they also produced $I l 2 \mathrm{rg} \mathrm{KO}$ rabbits by CRISPR/Cas 9 and demonstrated that these animals are immunodeficient [59].

\section{Where the ID Bunnies (Could) Rule}

Although five labs have reported the successful production of ID rabbits (Table 2), the application of this animal model has not been firmly established. The models, which included all significant ID genes that are targeted in mice (i.e., Foxn1, Rag1/2, Prkdc, and Il2rg), are not yet commercially available.

One challenge that is limiting the scale-up of the ID rabbit supply is their housing. There is no economically affordable germ-free caging system for rabbits yet. The team at the University of Michigan has developed a working protocol [89], in which a HEPA filtered, positive pressure, flexible film isolator cleanroom (BioBubble) is used to house ID rabbits. One bioBubble $(10 \times 12 \times 9$ feet $)$ can house up to 18 rabbits. Enhanced personal protective equipment (PPE) and sanitation practices are implemented and necessary to limit environmental contamination. ID rabbits also receive oral prophylactic sulfamethoxazole/trimethoprim antibiotics to reduce bacterial and Pneumocysis infections. These practices have proven effective; an ID rabbit colony with a daily census of greater than 30 is routinely housed at the facility. A broad adaption of these practices or similar ones is needed to eventually enable the use of ID rabbits in biomedical research. In addition, a reliable shipping method is yet to be developed to distribute ID rabbits. Alternatively, cryopreserved sperm [90] or embryos [91] can be used to rederive the animals at the destination institutes.

On the consumer end, ID rabbits are expected to help researchers fill the gap between mice and humans in basic and translational research. The larger size and longer lifespan would make immediate contributions. Examples include having a non-rodent ID model for FDA drug development studies, long term testing immunotherapies, increased ease of blood collection, the ability to collect larger tissue samples, and a larger platform for advanced surgical manipulation, and implantation of tissue-engineered constructs and medical devices. Other opportunities will undoubtedly arise, taking advantage of other unique features of rabbits; for example, an ID rabbit reconstituted with human lymphocytes for antibody or T-cell receptor (TCR) discovery. Below we provide our perspective on the future use of ID rabbits and describe how they could "rule", by elaborating upon several specific examples that we consider high priority projects to be developed in the next five years.

\subsection{Humanized Rabbits for Infectious Diseases}

Several infectious agents are human-specific, and animal models do not recapitulate many human diseases in part due to differences in biological response in major organ systems, such as the immune 
system [92,93]. Therefore, animal models that incorporate human organ systems could provide a means to bridge that species gap and enable the evaluation of the safety and efficacy of novel therapeutics [93]. Immunodeficient mouse models support human cell and tissue engraftment and development and are termed, humanized mice [94,95]. Humanized mouse models provide a means for studying human-specific infectious agents and human-specific biological effects. However, the limited lifespan and size of mice create a barrier for their use in preclinical studies [93]. To address these challenges, we are working to develop humanized ID rabbits by implanting human hematopoietic stem cells (HSC) and lymphoid tissues (Figure 1), a process which is similar to a procedure we reported in mice [96]. Preliminary data indicates that ID rabbits with only a single-gene knockout background (i.e., IL2RG KO), can be implanted with human immune cells and lymphoid tissues and can support their development (up to $>30 \%$ human CD45+/total PBMC). We anticipate that the efficiency can be improved on a multigenic background (e.g., Rag2 KO + Il2RG KO). Furthermore, transgenic integration or precise knock-in of human genes such as SIRP-alpha is expected to enhance the engraftment rates of human cells/tissues. Of note, the gene editing nuclease mediated precise gene knock-in has been reported in generating rabbit models [97] but has not yet been applied in ID rabbit engineering.

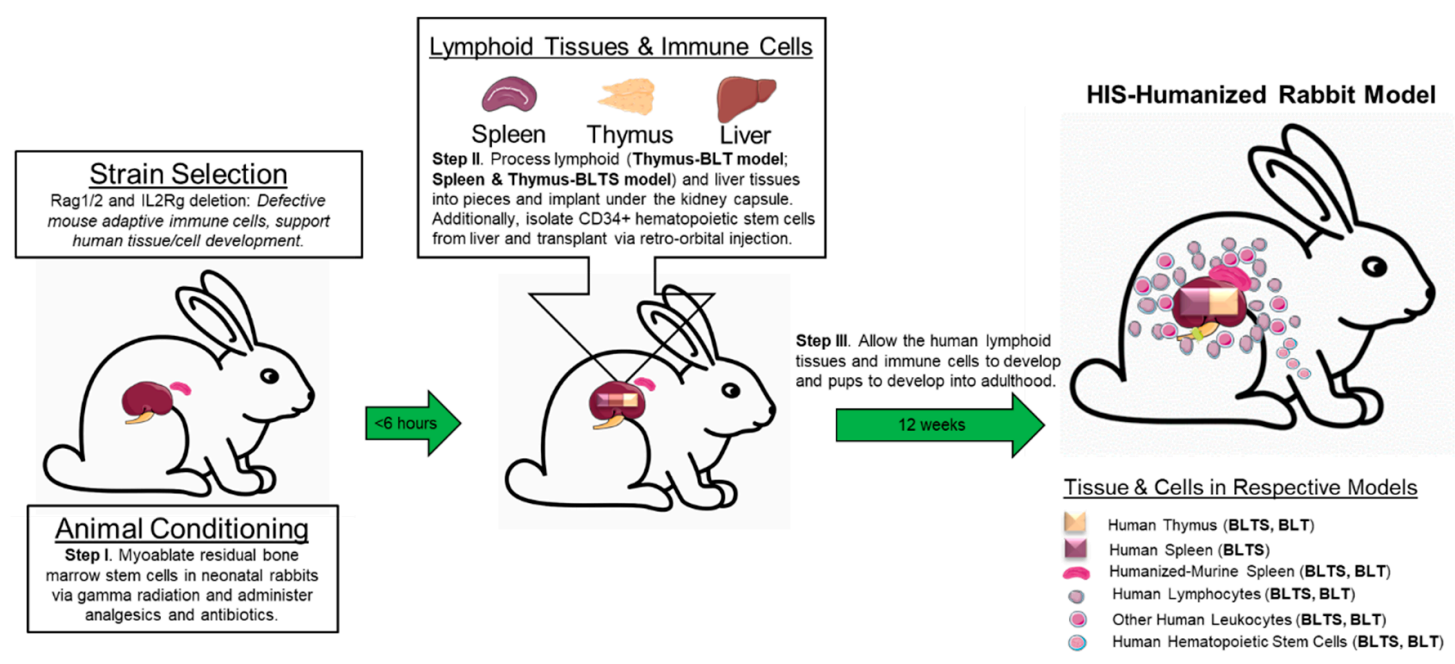

Figure 1. Illustration of the construction of the human immune system (HIS)-humanized rabbit models. First, immunodeficient rabbits, for example the ones with defects in recombination activating gene 1/2 (Rag1/2) and interleukin 2 receptor subunit gamma (IL2Rg), are developed and myoablated via gamma irradiation or busulfan, followed by the administration of antibiotics and analgesics at 1 to 2 weeks after birth. Second, to generate human lymphoid tissue xenografts along with autologous immune cell reconstitution in the rabbits, human fetal lymphoid tissue(s) and liver are processed into $1 \mathrm{~mm}^{3}$ pieces, and autologous CD34+ hematopoietic stem cells (HSCs) are isolated from the fetal liver via immunomagnetic selection of $\mathrm{CD} 34^{+}$cells. CD $34^{+}$HSCs are then transplanted into the neonatal rabbit via intrahepatic injection following renal capsule transplantation of the lymphoid tissues. Third, the transplanted rabbit is maintained under specific pathogen-free conditions and the lymphoid tissue(s), and/or immune cell reconstitution in the peripheral blood, are allowed to develop over a period of 3 months, resulting in the HIS-humanized rabbit model. BLTS: bone marrow stem cells, liver, thymus, and spleen. BLT: bone marrow stem cells, liver, and thymus.

\section{2. $C D X$ and $P D X$}

Tumor cell line-derived xenotransplant (CDX) and patient-derived tumor xenotransplant (PDX) are widely utilized procedures in cancer studies, where currently ID mice are used as the dominant host species [98]. It is realized, however, that the small size of the mouse sets a limitation on the size of tumor growth. More importantly, orthotopic transplantation, such as transplanting breast cancer cells to the host animal's mammary gland duct, is very challenging in ID mice. The availability of ID rabbits 
would provide a solution to these challenges and enable the study of more clinically applicable and large sized tumors in vivo.

\subsection{Testing of Stem Cell-Derived Blood Vessels}

Aortic aneurysm is a major threat to human health, for which aorta transplantation is the primary treatment option. Advances in patient-specific stem cell-derived blood vessels (SDBV) have made artificial vasculature a promising source of tissue for clinical procedures. However, studying SDBV transplantation in mouse models is technically challenging due to the differences in the size of the vasculature. ID rabbits, whose size is $>100$ times that of ID mice and comparable to that of a human infant, may permit practical evaluation of SDBVs.

\subsection{Preclinical Development of Gene Editing Therapy for SCID}

Gene-editing therapy (GETx) has emerged as a new therapeutic option for many human diseases, including primary immunodeficiency [99]. Preclinical testing of the efficacy and safety in ID rabbit models offers several advantages over the use of ID mouse models. For example, rabbits allow for relatively easy bone marrow aspiration through a survival procedure. After gene correction of the HSCs ex vivo, the cells can be transplanted back to the donor animal (i.e., autologous transplantation), a procedure that is not feasible in mice. Furthermore, long term efficacy and safety profiles of GETx can be documented in ID rabbits (but not in ID mice), which is essential given the substantial tumorigenesis risks observed in the clinical trials of conventional gene therapy strategies.

\subsection{Hepatocytes Regeneration}

The supply of primary hepatocytes represents a limiting factor in the study of liver biology and medicine due to the technical limitations of culturing primary human hepatocytes ex vivo. In this regard, an ID rabbit on the background of the Fah knockout may serve as an efficient bioreactor to produce human hepatocytes. This approach has been proven to work in mice, where the Fah gene deficiency leads to hepatocyte death, while the immunodeficiency allows engraftments of human hepatocytes [100]. The much larger size of the ID rabbit liver would make this production strategy attractive.

Rome wasn't built in a day; neither will be the "kingdom" of ID rabbits. It took a decade to produce the major lines, it is now imperative to robustly demonstrate the advantages of these new models over ID mice, a necessity before the broader scientific community adopts them in basic and translational research. Table 3 presents many examples of applications of immunodeficient rabbits. Work to continue to develop new lines and to optimize existing lines is also urgent. For example, the lack of the none-obese-diabetic (NOD) equivalent in rabbits calls for the generation of human Sirp-alpha transgenic (Tg) to minimize macrophage mediated immune-rejection [101]. Multigenic ID gene knockout, such as $\underline{R} a g 2 / I l 2 \mathrm{rg} K \mathrm{KO}(\mathrm{RG})$ should be developed as well to improve the engraftment efficiencies in xenotransplant experiments. Ultimately, the Sirp-alpha $\mathrm{Tg}$ line should be crossed with RG or the Prkdc/Il2rg KO (SG) line to establish NSG or NRG equivalent lines in rabbits. Challenging as they are, many of these goals are within reach, given that we are now armored with powerful gene editing tools and the completed rabbit genome project. It is not an overstatement that ID rabbits will contribute greatly to biomedical research, especially in the fields of regenerative medicine and cancer research in the near future. 
Table 3. Example applications of immunodeficient rabbits.

\begin{tabular}{l}
\hline 1. Transplantation of stem cell-derived blood vessels, and examine long term safety and efficacy. \\
\hline 2. PDX/CDX for drug development and screening for cancer and other diseases. \\
\hline 3. Humanized livers for pharmacokinetics and hepatotoxicity studies. \\
\hline 4. Long term efficacy and safety evaluation of neuronal stem cell-based therapy. \\
\hline 5. A bioreactor for production of human hepatocytes. \\
\hline 6. A bioreactor for production of human T-cells for CAR-T cell expansion. \\
\hline 7. A large animal model with the human immune system for the study of infectious diseases. \\
\hline 8. A large animal model with the human immune system for antibody discovery. \\
\hline 9. A large animal model with the human immune system for TCR discovery. \\
\hline 10. Development and validation of imaging and diagnostic tools. \\
\hline 11. Study graft-versus-host disease (GVHD) in a large animal model. \\
\hline 12. Development of gene therapy and/or gene editing therapy for primary immunodeficient diseases.
\end{tabular}

Author Contributions: J.S., M.B. and J.X. conceived the idea. J.S., B.P., D.Y., J.Z., Y.A., Y.E.C., M.B. and J.X. wrote the manuscript. All authors have read and agreed to the published version of the manuscript.

Funding: This work was funded by the National Institutes of Health (OD024789 to J.X. and M.B. and HL147527 to Y.E.C.).

Conflicts of Interest: The authors declare no conflict of interest.

\section{References}

1. Evans, M.J.; Kaufman, M.H. Establishment in culture of pluripotential cells from mouse embryos. Nat. Cell Biol. 1981, 292, 154-156. [CrossRef] [PubMed]

2. Martin, G.R. Isolation of a pluripotent cell line from early mouse embryos cultured in medium conditioned by teratocarcinoma stem cells. Proc. Natl. Acad. Sci. USA 1981, 78, 7634-7638. [CrossRef] [PubMed]

3. Gossler, A.; Doetschman, T.; Korn, R.; Serfling, E.; Kemler, R. Transgenesis by means of blastocyst-derived embryonic stem cell lines. Proc. Natl. Acad. Sci. USA 1986, 83, 9065-9069. [CrossRef] [PubMed]

4. Robertson, E.J.; Bradley, A.; Kuehn, M.; Evans, M.J. Germ-line transmission of genes introduced into cultured pluripotential cells by retroviral vector. Nat. Cell Biol. 1986, 323, 445-448. [CrossRef] [PubMed]

5. Vandamme, T.F. Use of rodents as models of human diseases. J. Pharm. BioAllied Sci. 2014, 6, 2-9. [CrossRef]

6. Fischer, A.; Notarangelo, L.D.; Neven, B.; Cavazzana, M.; Puck, J.M. Severe combined immunodeficiencies and related disorders. Nat. Rev. Dis. Prim. 2015, 1, 15061. [CrossRef]

7. Blundell, M.P.; Kinnon, C. Animal Models of Human Primary Immunodeficiency Diseases. eLS 2012. [CrossRef]

8. Shultz, L.D.; Ishikawa, F.; Greiner, D.L. Humanized mice in translational biomedical research. Nat. Rev. Immunol. 2007, 7, 118-130. [CrossRef]

9. Cibelli, J.; Emborg, M.E.; Prockop, D.J.; Roberts, M.; Schatten, G.; Rao, M.; Harding, J.; Mirochnitchenko, O. Strategies for Improving Animal Models for Regenerative Medicine. Cell Stem Cell 2013, 12, 271-274. [CrossRef]

10. Cavazzana-Calvo, M.; Hacein-Bey, S.; de Saint Basile, G.; Gross, F.; Yvon, E.; Nusbaum, P.; Selz, F.; Hue, C.; Certain, S.; Casanova, J.L.; et al. Gene therapy of human severe combined immunodeficiency (SCID)-X1 disease. Science 2000, 288, 669-672. [CrossRef]

11. Hacein-Bey-Abina, S.; Von Kalle, C.; Schmidt, M.; Le Deist, F.; Wulffraat, N.; McIntyre, E.; Radford, I.; Villeval, J.-L.; Fraser, C.C.; Cavazzana-Calvo, M.; et al. A Serious Adverse Event after Successful Gene Therapy for X-Linked Severe Combined Immunodeficiency. N. Engl. J. Med. 2003, 348, 255-256. [CrossRef] [PubMed] 
12. Howe, S.J.; Mansour, M.R.; Schwarzwaelder, K.; Bartholomae, C.; Hubank, M.; Kempski, H.; Brugman, M.H.; Pike-Overzet, K.; Chatters, S.J.; De Ridder, D.; et al. Insertional mutagenesis combined with acquired somatic mutations causes leukemogenesis following gene therapy of SCID-X1 patients. J. Clin. Investig. 2008, 118, 3143-3150. [CrossRef] [PubMed]

13. Hacein-Bey-Abina, S.; Garrigue, A.; Wang, G.P.; Soulier, J.; Lim, A.; Morillon, E.; Clappier, E.; Caccavelli, L.; Delabesse, E.; Beldjord, K.; et al. Insertional oncogenesis in 4 patients after retrovirus-mediated gene therapy of SCID-X1. J. Clin. Investig. 2008, 118, 3132-3142. [CrossRef]

14. Geurts, A.M.; Cost, G.J.; Freyvert, Y.; Zeitler, B.; Miller, J.C.; Choi, V.M.; Jenkins, S.S.; Wood, A.; Cui, X.; Meng, X.; et al. Knockout Rats via Embryo Microinjection of Zinc-Finger Nucleases. Science 2009, 325, 433. [CrossRef]

15. Miller, J.C.; Tan, S.; Qiao, G.; Barlow, K.A.; Wang, J.; Xia, D.; Meng, X.; Paschon, D.E.; Leung, E.; Hinkley, S.J.; et al. A TALE nuclease architecture for efficient genome editing. Nat. Biotechnol. 2010, 29, 143-148. [CrossRef]

16. Hockemeyer, D.; Wang, H.; Kiani, S.; Lai, C.S.; Gao, Q.; Cassady, J.P.; Cost, G.J.; Zhang, L.; Santiago, Y.; Miller, J.C.; et al. Genetic engineering of human pluripotent cells using TALE nucleases. Nat. Biotechnol. 2011, 29, 731-734. [CrossRef] [PubMed]

17. Moscou, M.J.; Bogdanove, A.J. A Simple Cipher Governs DNA Recognition by TAL Effectors. Science 2009, 326, 1501. [CrossRef] [PubMed]

18. Boch, J.; Scholze, H.; Schornack, S.; Landgraf, A.; Hahn, S.; Kay, S.; Lahaye, T.; Nickstadt, A.; Bonas, U. Breaking the Code of DNA Binding Specificity of TAL-Type III Effectors. Science 2009, 326, 1509-1512. [CrossRef]

19. Cong, L.; Ran, F.A.; Cox, D.; Lin, S.; Barretto, R.; Habib, N.; Hsu, P.D.; Wu, X.; Jiang, W.; Marraffini, L.; et al. Multiplex Genome Engineering Using CRISPR/Cas Systems. Science 2013, 339, 819-823. [CrossRef] [PubMed]

20. Mali, P.; Yang, L.; Esvelt, K.M.; Aach, J.; Guell, M.; Dicarlo, J.E.; Norville, J.E.; Church, G.M. RNA-Guided Human Genome Engineering via Cas9. Science 2013, 339, 823-826. [CrossRef]

21. Zhao, J.; Lai, L.; Ji, W.; Zhou, Q. Genome editing in large animals: Current status and future prospects. Natl. Sci. Rev. 2019, 6, 402-420. [CrossRef]

22. Wiler, R.; Leber, R.; Moore, B.B.; VanDyk, L.F.; Perryman, L.E.; Meek, K. Equine severe combined immunodeficiency: A defect in $\mathrm{V}(\mathrm{D}) \mathrm{J}$ recombination and DNA-dependent protein kinase activity. Proc. Natl. Acad. Sci. USA 1995, 92, 11485-11489. [CrossRef] [PubMed]

23. Shin, E.K.; Perryman, L.E.; Meek, K. A kinase-negative mutation of DNA-PK(CS) in equine SCID results in defective coding and signal joint formation. J. Immunol. 1997, 158, 3565-3569. [PubMed]

24. Henthorn, P.S.; Somberg, R.L.; Fimiani, V.M.; Puck, J.M.; Patterson, D.F.; Felsburg, P.J. IL-2R $\gamma$ Gene Microdeletion Demonstrates That Canine X-Linked Severe Combined Immunodeficiency Is a Homologue of the Human Disease. Genomics 1994, 23, 69-74. [CrossRef] [PubMed]

25. Somberg, R.L.; Pullen, R.P.; Casal, M.L.; Patterson, D.F.; Felsburg, P.J.; Henthorn, P.S. A single nucleotide insertion in the canine interleukin-2 receptor gamma chain results in X-linked severe combined immunodeficiency disease. Veter. Immunol. Immunopathol. 1995, 47, 203-213. [CrossRef]

26. Meek, K.; Kienker, L.; Dallas, C.; Wang, W.; Dark, M.J.; Venta, P.J.; Huie, M.L.; Hirschhorn, R.; Bell, T. SCID in Jack Russell Terriers: A New Animal Model of DNA-PKcs Deficiency. J. Immunol. 2001, 167, $2142-2150$. [CrossRef]

27. Ding, Q.; Bramble, L.; Yuzbasiyan-Gurkan, V.; Bell, T.; Meek, K. DNA-PKcs mutations in dogs and horses: Allele frequency and association with neoplasia. Gene 2002, 283, 263-269. [CrossRef]

28. Mashimo, T.; Takizawa, A.; Voigt, B.; Yoshimi, K.; Hiai, H.; Kuramoto, T.; Serikawa, T. Generation of Knockout Rats with X-Linked Severe Combined Immunodeficiency (X-SCID) Using Zinc-Finger Nucleases. PLoS ONE 2010, 5, e8870. [CrossRef]

29. Mashimo, T.; Takizawa, A.; Kobayashi, J.; Kunihiro, Y.; Yoshimi, K.; Ishida, S.; Tanabe, K.; Yanagi, A.; Tachibana, A.; Hirose, J.; et al. Generation and Characterization of Severe Combined Immunodeficiency Rats. Cell Rep. 2012, 2, 685-694. [CrossRef]

30. Yang, X.; Zhou, J.; He, J.; Liu, J.; Wang, H.; Liu, Y.; Jiang, T.; Zhang, Q.; Fu, X.; Xu, Y. An Immune System-Modified Rat Model for Human Stem Cell Transplantation Research. Stem Cell Rep. 2018, 11, 514-521. [CrossRef] 
31. He, D.; Zhang, J.; Wu, W.; Yi, N.; He, W.; Lu, P.; Li, B.; Yang, N.; Wang, D.; Xue, Z.; et al. A novel immunodeficient rat model supports human lung cancer xenografts. FASEB J. 2018, 33, 140-150. [CrossRef] [PubMed]

32. Ménoret, S.; Ouisse, L.-H.; Tesson, L.; Delbos, F.; Garnier, D.; Remy, S.; Usal, C.; Concordet, J.-P.; Giovannangeli, C.; Chenouard, V.; et al. Generation of Immunodeficient Rats with Rag1 and Il2rg Gene Deletions and Human Tissue Grafting Models. Transplantation 2018, 102, 1271-1278. [CrossRef] [PubMed]

33. Suzuki, S.; Iwamoto, M.; Saito, Y.; Fuchimoto, D.; Sembon, S.; Suzuki, M.; Mikawa, S.; Hashimoto, M.; Aoki, Y.; Najima, Y.; et al. Il2rg Gene-Targeted Severe Combined Immunodeficiency Pigs. Cell Stem Cell 2012, 10, 753-758. [CrossRef]

34. Watanabe, M.; Nakano, K.; Matsunari, H.; Matsuda, T.; Maehara, M.; Kanai, T.; Kobayashi, M.; Matsumura, Y.; Sakai, R.; Kuramoto, M.; et al. Generation of Interleukin-2 Receptor Gamma Gene Knockout Pigs from Somatic Cells Genetically Modified by Zinc Finger Nuclease-Encoding mRNA. PLoS ONE 2013, 8, e76478. [CrossRef] [PubMed]

35. Hara, H.; Shibata, H.; Nakano, K.; Abe, T.; Uosaki, H.; Ohnuki, T.; Hishikawa, S.; Kunita, S.; Watanabe, M.; Nureki, O.; et al. Production and rearing of germ-free X-SCID pigs. Exp. Anim. 2017, 67, 139-146. [CrossRef]

36. Suzuki, S.; Iwamoto, M.; Hashimoto, M.; Suzuki, M.; Nakai, M.; Fuchimoto, D.; Sembon, S.; Eguchi-Ogawa, T.; Uenishi, H.; Onishi, A. Generation and characterization of RAG2 knockout pigs as animal model for severe combined immunodeficiency. Vet. Immunol. Immunopathol. 2016, 178, 37-49. [CrossRef]

37. Boettcher, A.N.; Li, Y.; Ahrens, A.P.; Kiupel, M.; Byrne, K.A.; Loving, C.L.; Cino-Ozuna, A.G.; Wiarda, J.E.; Adur, M.; Schultz, B.; et al. Novel Engraftment and T Cell Differentiation of Human Hematopoietic Cells in ART-/-IL2RG-/Y SCID Pigs. Front. Immunol. 2020, 11. [CrossRef]

38. Choi, Y.-J.; Lee, K.; Park, W.-J.; Kwon, D.-N.; Park, C.; Do, J.T.; Song, H.; Cho, S.-K.; Park, K.-W.; Brown, A.N.; et al. Partial loss of interleukin 2 receptor gamma function in pigs provides mechanistic insights for the study of human immunodeficiency syndrome. Oncotarget 2016, 7, 50914-50926. [CrossRef]

39. Kang, J.-T.; Cho, B.; Ryu, J.; Ray, C.; Lee, E.-J.; Yun, Y.-J.; Ahn, S.; Lee, J.; Ji, D.-Y.; Jue, N.; et al. Biallelic modification of IL2RG leads to severe combined immunodeficiency in pigs. Reprod. Biol. Endocrinol. 2016, 14, 1-9. [CrossRef]

40. Lei, S.; Ryu, J.; Wen, K.; Twitchell, E.; Bui, T.; Ramesh, A.; Weiss, M.; Li, G.; Samuel, H.; Clark-Deener, S.; et al. Increased and prolonged human norovirus infection in RAG2/IL2RG deficient gnotobiotic pigs with severe combined immunodeficiency. Sci. Rep. 2016, 6, 25222. [CrossRef]

41. Sato, K.; Oiwa, R.; Kumita, W.; Henry, R.; Sakuma, T.; Ito, R.; Nozu, R.; Inoue, T.; Katano, I.; Sato, K.; et al. Generation of a Nonhuman Primate Model of Severe Combined Immunodeficiency Using Highly Efficient Genome Editing. Cell Stem Cell 2016, 19, 127-138. [CrossRef] [PubMed]

42. Zschemisch, N.-H.; Glage, S.; Wedekind, D.; Weinstein, E.J.; Cui, X.; Dorsch, M.; Hedrich, H. Zinc-finger nuclease mediated disruption of Rag1 in the LEW/Ztm rat. BMC Immunol. 2012, 13, 60. [CrossRef] [PubMed]

43. Ménoret, S.; Fontanière, S.; Jantz, D.; Tesson, L.; Thinard, R.; Rémy, S.; Usal, C.; Ouisse, L.; Fraichard, A.; Anegon, I. Generation of Rag1-knockout immunodeficient rats and mice using engineered meganucleases. FASEB J. 2012, 27, 703-711. [CrossRef] [PubMed]

44. Ito, T.; Sendai, Y.; Yamazaki, S.; Seki-Soma, M.; Hirose, K.; Watanabe, M.; Fukawa, K.; Nakauchi, H. Generation of Recombination Activating Gene-1-Deficient Neonatal Piglets: A Model of T and B Cell Deficient Severe Combined Immune Deficiency. PLoS ONE 2014, 9, e113833. [CrossRef] [PubMed]

45. Huang, J.; Guo, X.; Fan, N.; Song, J.; Zhao, B.; Ouyang, Z.; Liu, Z.; Zhao, Y.; Yan, Q.; Yi, X.; et al. RAG1/2 Knockout Pigs with Severe Combined Immunodeficiency. J. Immunol. 2014, 193, 1496-1503. [CrossRef] [PubMed]

46. Miao, J.-X.; Ying, B.; Li, R.; Tollefson, A.E.; Spencer, J.F.; Wold, W.S.M.; Song, S.-H.; Kong, I.; Toth, K.; Wang, Y.; et al. Characterization of an N-Terminal Non-Core Domain of RAG1 Gene Disrupted Syrian Hamster Model Generated by CRISPR Cas9. Viruses 2018, 10, 243. [CrossRef] [PubMed]

47. Liu, Q.; Fan, C.; Zhou, S.; Guo, Y.; Zuo, Q.; Ma, J.; Liu, S.; Wu, X.; Peng, Z.; Fan, T.; et al. Bioluminescent imaging of vaccinia virus infection in immunocompetent and immunodeficient rats as a model for human smallpox. Sci. Rep. 2015, 5, 11397. [CrossRef] 
48. Noto, F.K.; Steffey, V.A.; Tong, M.; Ravichandran, K.; Zhang, W.; Arey, A.; McClain, C.B.; Ostertag, E.; Mazhar, S.; Sangodkar, J.; et al. Sprague Dawley Rag2-Null Rats Created from Engineered Spermatogonial Stem Cells Are Immunodeficient and Permissive to Human Xenografts. Mol. Cancer Ther. 2018, 17, 2481-2489. [CrossRef]

49. Lee, K.; Kwon, D.-N.; Ezashi, T.; Choi, Y.-J.; Park, C.; Ericsson, A.C.; Brown, A.N.; Samuel, M.S.; Park, K.-W.; Walters, E.M.; et al. Engraftment of human iPS cells and allogeneic porcine cells into pigs with inactivated RAG2 and accompanying severe combined immunodeficiency. Proc. Natl. Acad. Sci. USA 2014, 111, 7260-7265. [CrossRef]

50. Ménoret, S.; Iscache, A.-L.; Tesson, L.; Rémy, S.; Usal, C.; Osborn, M.J.; Cost, G.J.; Brüggemann, M.; Buelow, R.; Anegon, I. Characterization of immunoglobulin heavy chain knockout rats. Eur. J. Immunol. 2010, 40, 2932-2941. [CrossRef]

51. Panzer, S.E.; Wilson, N.A.; Verhoven, B.M.; Xiang, D.; Rubinstein, C.D.; Redfield, R.R.; Zhong, W.; Reese, S.R. Complete B Cell Deficiency Reduces Allograft Inflammation and Intragraft Macrophages a Rat Kidney Transplant Model. Transplantation 2017, 102, 396-405. [CrossRef]

52. Chen, F.; Wang, Y.; Yuan, Y.; Zhang, W.; Ren, Z.; Jin, Y.; Liu, X.; Xiong, Q.; Chen, Q.; Zhang, M.; et al. Generation of B Cell-Deficient Pigs by Highly Efficient CRISPR/Cas9-Mediated Gene Targeting. J. Genet. Genom. 2015, 42, 437-444. [CrossRef]

53. Bell, T.G.; Butler, K.L.; Sill, H.B.; Stickle, J.E.; Ramos-Vara, J.A.; Dark, M.J. Autosomal Recessive Severe Combined Immunodeficiency of Jack Russell Terriers. J. Veter. Diagn. Investig. 2002, 14, 194-204. [CrossRef]

54. Goto, T.; Hara, H.; Nakauchi, H.; Hochi, S.; Hirabayashi, M. Hypomorphic phenotype of Foxn1 gene-modified rats by CRISPR/Cas9 system. Transgenic Res. 2016, 25, 533-544. [CrossRef] [PubMed]

55. Ozuna, A.G.C.; Rowland, R.R.R.; Nietfeld, J.C.; Kerrigan, M.A.; Dekkers, J.C.M.; Wyatt, C. Preliminary Findings of a Previously Unrecognized Porcine Primary Immunodeficiency Disorder. Veter. Pathol. 2012, 50, 144-146. [CrossRef] [PubMed]

56. Waide, E.H.; Dekkers, J.C.M.; Ross, J.W.; Rowland, R.R.R.; Wyatt, C.R.; Ewen, C.L.; Evans, A.B.; Thekkoot, D.M.; Boddicker, N.J.; Serão, N.V.L.; et al. Not All SCID Pigs Are Created Equally: Two Independent Mutations in the Artemis Gene Cause SCID in Pigs. J. Immunol. 2015, 195, 3171-3179. [CrossRef]

57. Jasper, P.J.; Rhee, K.-J.; Kalis, S.L.; Sethupathi, P.; Yam, P.-C.; Zhai, S.-K.; Knight, K. B lymphocyte deficiency in IgH-transgenic rabbits. Eur. J. Immunol. 2007, 37, 2290-2299. [CrossRef] [PubMed]

58. Song, J.; Yang, N.; Ruan, J.; Zhang, J.; Chen, Y.E.; Xu, J. Production of immunodeficient rabbits by multiplex embryo transfer and multiplex gene targeting. Sci. Rep. 2017, 7, 12202. [CrossRef]

59. Hashikawa, Y.; Hayashi, R.; Tajima, M.; Okubo, T.; Azuma, S.; Kuwamura, M.; Takai, N.; Osada, Y.; Kunihiro, Y.; Mashimo, T.; et al. Generation of knockout rabbits with X-linked severe combined immunodeficiency (X-SCID) using CRISPR/Cas9. Sci. Rep. 2020, 10, 9957. [CrossRef] [PubMed]

60. Song, J.; Zhong, J.; Guo, X.; Chen, Y.; Zou, Q.; Huang, J.; Li, X.; Zhang, Q.; Jiang, Z.; Tang, C.; et al. Generation of RAG 1- and 2-deficient rabbits by embryo microinjection of TALENs. Cell Res. 2013, 23, 1059-1062. [CrossRef]

61. Flisikowska, T.; Thorey, I.S.; Offner, S.; Ros, F.; Lifke, V.; Zeitler, B.; Rottmann, O.; Vincent, A.; Zhang, L.; Jenkins, S.; et al. Efficient Immunoglobulin Gene Disruption and Targeted Replacement in Rabbit Using Zinc Finger Nucleases. PLoS ONE 2011, 6, e21045. [CrossRef] [PubMed]

62. Esteves, P.J.; Abrantes, J.; Baldauf, H.-M.; Benmohamed, L.; Chen, Y.; Christensen, N.; González-Gallego, J.; Giacani, L.; Hu, J.; Kaplan, G.; et al. The wide utility of rabbits as models of human diseases. Exp. Mol. Med. 2018, 50, 1-10. [CrossRef] [PubMed]

63. Fan, J.; Watanabe, T. Transgenic rabbits as therapeutic protein bioreactors and human disease models. Pharmacol. Ther. 2003, 99, 261-282. [CrossRef]

64. Peng, X. Transgenic Rabbit Models for Studying Human Cardiovascular Diseases. Comp. Med. 2012,62, 472-479.

65. Peng, X.; Knouse, J.A.; Hernon, K.M. Rabbit Models for Studying Human Infectious Diseases. Comp. Med. 2015, 65, 499-507.

66. Fan, J.; Kitajima, S.; Watanabe, T.; Xu, J.; Zhang, J.; Liu, E.; Chen, Y.E. Rabbit models for the study of human atherosclerosis: From pathophysiological mechanisms to translational medicine. Pharmacol. Ther. 2015, 146, 104-119. [CrossRef]

67. Pearce, J.M.S. Louis Pasteur and Rabies: A brief note. J. Neurol. Neurosurg. Psychiatry 2002, 73, 82. [CrossRef] 
68. Cambau, E.; Drancourt, M. Steps towards the discovery of Mycobacterium tuberculosis by Robert Koch, 1882. Clin. Microbiol. Infect. 2014, 20, 196-201. [CrossRef]

69. Epstein, F.H.; Brown, M.S.; Kita, T.; Brown, M.S. Defective Lipoprotein Receptors and Atherosclerosis. N. Engl. J. Med. 1983, 309, 288-296. [CrossRef]

70. Chang, M.C. Fertilization of Rabbit Ova in vitro. Nat. Cell Biol. 1959, 184, 466-467. [CrossRef]

71. Biggers, J.D. Walter Heape, FRS: A pioneer in reproductive biology. Centenary of his embryo transfer experiments. Reproduction 1991, 93, 173-186. [CrossRef]

72. Song, J.; Zhang, J.; Xu, J.; Garcia-Barrio, M.; Chen, Y.E.; Yang, D. Genome engineering technologies in rabbits. J. Biomed. Res. 2020, 34, 1-13. [CrossRef]

73. Mage, R.G.; Esteves, P.J.; Rader, C. Rabbit models of human diseases for diagnostics and therapeutics development. Dev. Comp. Immunol. 2019, 92, 99-104. [CrossRef] [PubMed]

74. Pinheiro, A.; Neves, F.; De Matos, A.L.; Abrantes, J.; Van Der Loo, W.; Mage, R.; Esteves, P.J. An overview of the lagomorph immune system and its genetic diversity. Immunogenetics 2015, 68, 83-107. [CrossRef]

75. Pinheiro, A.; Lanning, D.; Alves, P.C.; Mage, R.G.; Knight, K.L.; Van Der Loo, W.; Esteves, P.J. Molecular bases of genetic diversity and evolution of the immunoglobulin heavy chain variable region (IGHV) gene locus in leporids. Immunogenetics 2011, 63, 397-408. [CrossRef]

76. Katzourakis, A.; Tristem, M.; Pybus, O.G.; Gifford, R.J. Discovery and analysis of the first endogenous lentivirus. Proc. Natl. Acad. Sci. USA 2007, 104, 6261-6265. [CrossRef]

77. Alves, J.M.; Carneiro, M.; Cheng, J.Y.; De Matos, A.L.; Rahman, M.M.; Loog, L.; Campos, P.F.; Wales, N.; Eriksson, A.; Manica, A.; et al. Parallel adaptation of rabbit populations to myxoma virus. Science 2019, 363, 1319-1326. [CrossRef]

78. Abrantes, J.; Van Der Loo, W.; Le Pendu, J.; Esteves, P.J. Rabbit haemorrhagic disease (RHD) and rabbit haemorrhagic disease virus (RHDV): A review. Vet. Res. 2012, 43, 12. [CrossRef]

79. Song, J.; Wang, G.; Hoenerhoff, M.J.; Ruan, J.; Yang, D.; Zhang, J.; Yang, J.; Lester, P.A.; Sigler, R.; Bradley, M.; et al. Bacterial and Pneumocystis Infections in the Lungs of Gene-Knockout Rabbits with Severe Combined Immunodeficiency. Front. Immunol. 2018, 9. [CrossRef] [PubMed]

80. Xue, F.; Ma, Y.; Chen, Y.E.; Zhang, J.; Lin, T.-A.; Chen, C.-H.; Lin, W.-W.; Roach, M.; Ju, J.-C.; Yang, L.; et al. Recombinant Rabbit Leukemia Inhibitory Factor and Rabbit Embryonic Fibroblasts Support the Derivation and Maintenance of Rabbit Embryonic Stem Cells. Cell. Reprogramming 2012, 14, 364-376. [CrossRef] [PubMed]

81. Du, F.; Xu, J.; Gao, S.; Sung, L.Y.; Stone, D.; Joyner, M.; Zhang, J.; Chaubal, S.; Tian, X.; Chen, Y.E.; et al. 31 full-term and live rabbit clones produced by somatic cell nuclear transfer. Reprod. Fertil. Dev. 2006, 18, 124. [CrossRef]

82. Lai, L.; Prather, R.S. Creating genetically modified pigs by using nuclear transfer. Reprod. Biol. Endocrinol. 2003, 1, 82. [CrossRef] [PubMed]

83. Ramsoondar, J.J.; Machaty, Z.; Costa, C.; Williams, B.L.; Fodor, W.L.; Bondioli, K.; Duffy, D.M. Production of

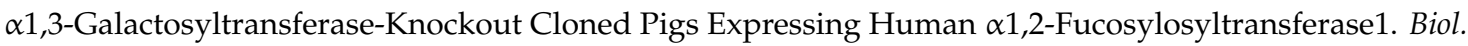
Reprod. 2003, 69, 437-445. [CrossRef]

84. Lai, L.; Kwangwook, P.; Cheong, H.-T.; Kühholzer, B.; Samuel, M.; Bonk, A.; Im, G.-S.; Rieke, A.; Day, B.N.; Murphy, C.N.; et al. Transgenic pig expressing the enhanced green fluorescent protein produced by nuclear transfer using colchicine-treated fibroblasts as donor cells. Mol. Reprod. Dev. 2002, 62, 300-306. [CrossRef] [PubMed]

85. Schnieke, A.E.; Kind, A.J.; Ritchie, W.A.; Mycock, K.; Scott, A.R.; Ritchie, M.; Wilmut, I.; Colman, A.; Campbell, K.H.S. Human Factor IX Transgenic Sheep Produced by Transfer of Nuclei from Transfected Fetal Fibroblasts. Science 1997, 278, 2130-2133. [CrossRef] [PubMed]

86. McCreath, K.J.; Howcroft, J.; Campbell, K.H.S.; Colman, A.D.; Schnieke, A.; Kind, A. Production of gene-targeted sheep by nuclear transfer from cultured somatic cells. Nat. Cell Biol. 2000, 405, 1066-1069. [CrossRef]

87. Cibelli, J.B.; Stice, S.L.; Golueke, P.J.; Kane, J.J.; Jerry, J.; Blackwell, C.; De León, F.A.P.; Robl, J.M. Cloned Transgenic Calves Produced from Nonquiescent Fetal Fibroblasts. Science 1998, 280, 1256-1258. [CrossRef]

88. Yan, Q.; Zhang, Q.; Yang, H.; Zou, Q.; Tang, C.; Fan, N.; Lai, L. Generation of multi-gene knockout rabbits using the Cas9/gRNA system. Cell Regen. 2014, 3, 12. [CrossRef] 
89. Ballou, S.M.; Song, J.; Xu, J.; Lester, P.A. Husbandry Efforts for Housing and Maintaining Immunodeficient Transgenic Rabbits. Lab. Anim. Sci. Prof. 2019, 7, 58-59. Available online: https://www.aalas.org/articles/ 2019/09/01/husbandry-efforts-for-housing-and-maintaining-immunodeficient--transgenic-rabbits (accessed on 19 October 2020).

90. Mocé, E.; Vicente, J.S. Rabbit sperm cryopreservation: A review. Anim. Reprod. Sci. 2009, 110, 1-24. [CrossRef]

91. Lin, T.; Chen, C.; Sung, L.-Y.; Carter, M.; Chen, Y.; Du, F.; Ju, J.; Xu, J. Open-pulled straw vitrification differentiates cryotolerance of in vitro cultured rabbit embryos at the eight-cell stage. Theriogenology 2011, 75, 760-768. [CrossRef]

92. Yue, F.; The Mouse ENCODE Consortium; Cheng, Y.; Breschi, A.; Vierstra, J.; Wu, W.; Ryba, T.; Sandstrom, R.; Samantha, K.; Davis, C.; et al. A comparative encyclopedia of DNA elements in the mouse genome. Nat. Cell Biol. 2014, 515, 355-364. [CrossRef]

93. Shultz, L.D.; Brehm, M.A.; Garcia-Martinez, J.V.; Greiner, D.L. Humanized mice for immune system investigation: Progress, promise and challenges. Nat. Rev. Immunol. 2012, 12, 786-798. [CrossRef] [PubMed]

94. Akkina, R.; Barber, D.L.; Bility, M.T.; Bissig, K.-D.; Burwitz, B.J.; Eichelberg, K.; Endsley, J.J.; Garcia, J.V.; Hafner, R.; Karakousis, P.C.; et al. Small Animal Models for Human Immunodeficiency Virus (HIV), Hepatitis B, and Tuberculosis: Proceedings of an NIAID Workshop. Curr. HIV Res. 2020, 18, 19-28. [CrossRef]

95. Allen, T.M.; Brehm, M.A.; Bridges, S.; Ferguson, S.; Kumar, P.; Mirochnitchenko, O.; Palucka, K.; Pelanda, R.; Sanders-Beer, B.; Shultz, L.D.; et al. Humanized immune system mouse models: Progress, challenges and opportunities. Nat. Immunol. 2019, 20, 770-774. [CrossRef]

96. Samal, J.; Kelly, S.; Na-Shatal, A.; Elhakiem, A.; Das, A.; Ding, M.; Sanyal, A.; Gupta, P.; Melody, K.; Roland, B.; et al. Human immunodeficiency virus infection induces lymphoid fibrosis in the BM-liver-thymus-spleen humanized mouse model. JCI Insight 2018, 3. [CrossRef]

97. Song, J.; Yang, D.; Xu, J.; Zhu, T.; Chen, Y.E.; Zhang, J. RS-1 enhances CRISPR/Cas9- and TALEN-mediated knock-in efficiency. Nat. Commun. 2016, 7, 10548. [CrossRef]

98. Day, C.-P.; Merlino, G.; Van Dyke, T. Preclinical Mouse Cancer Models: A Maze of Opportunities and Challenges. Cell 2015, 163, 39-53. [CrossRef] [PubMed]

99. Zhang, Z.Y.; Thrasher, A.J.; Zhang, F. Gene therapy and genome editing for primary immunodeficiency diseases. Genes Dis. 2019, 7, 38-51. [CrossRef]

100. Azuma, H.; Paulk, N.K.; Ranade, A.; Dorrell, C.; Al-Dhalimy, M.; Ellis, E.; Strom, S.; Kay, M.A.; Finegold, M.J.; Grompe, M. Robust expansion of human hepatocytes in Fah-/-/Rag2-/-/Il2rg-/- mice. Nat. Biotechnol. 2007, 25, 903-910. [CrossRef] [PubMed]

101. Takenaka, K.; Prasolava, T.K.; Wang, J.C.Y.; Mortin-Toth, S.M.; Khalouei, S.; Gan, O.I.; Dick, J.E.; Danska, J.S. Polymorphism in Sirpa modulates engraftment of human hematopoietic stem cells. Nat. Immunol. 2007, 8, 1313-1323. [CrossRef]

Publisher's Note: MDPI stays neutral with regard to jurisdictional claims in published maps and institutional affiliations.

(C) 2020 by the authors. Licensee MDPI, Basel, Switzerland. This article is an open access article distributed under the terms and conditions of the Creative Commons Attribution (CC BY) license (http://creativecommons.org/licenses/by/4.0/). 